\title{
Bimbingan dan Pelatihan Penyusunan Laporan Keuangan Bank Sampah yang Dikelola oleh Yayasan Kumala
}

\author{
Abdul Muslim ${ }^{\mathrm{a}, 1, *}$ \\ ${ }^{a}$ Institut Ilmu Sosial dan Manajemen STIAMI, Jakarta, Indonesia \\ 1 abdulmuslim78@ gmail.com * \\ * corresponding author
}

ARTICLE INFO

Article History

Received,22-09-2020

Revised,16-01-2021

Accepted,20-01-2021

Keywords

The Foundation's Financial

Statement:

SAK Guidelines No. 45

\begin{abstract}
Kumala Foundation is a form of non-profit entity, the preparation of the entity's financial statements has been regulated in the applicable reporting standard guidelines No. 45 (Guideline for SAK No. 45). The Kumala Foundation is located at Sungai Bambu road, Tanjung Priok, North Jakarta. It turns out that it has had problems in the preparation and reporting of reports because they did not comply with the applicable standards.

Conducting guidance and training in preparing financial reports can be a solution to these problems, so that the Kumala Foundation can increase their financial accountability. The initial stages carried out in the guidance and training are learning activities, conducting reviews, following up on the results of reviews, and mentoring during the service period. In addition, the use of the system is expected to facilitate the process of recording financial statements
\end{abstract}

\section{PENDAHULUAN}

Yayasan sosial didirikan dengan berorientasi pada kegiatan keagamaan, kesejahteraan, peningkatan kualitas hidup sesuai dengan ketentuan perundangan yang berlaku. Yayasan sosial dibentuk bukan untuk mencari keuntungan, namun tetap membutuhkan dana dari kegiatan bisnis, disamping dari dana dari para donatur.

Saat ini mungkin ada beberapa yayasan yang ternyata memiliki asset yang banyak, sehingga dibutuhkan penyusunan laporan keuangan yang baik dan benar agar dapat meningkatkan akuntabilitas keuangan entitas. Laporan keuangan sendiri adalah suatu penyajian posisi keuangan secara terstruktur atas seluruh aset dan sumber daya yang dimiliki oleh suatu entitas.

Yayasan Kumala (Kreatif Usaha Mandiri Alami) adalah sebuah organisasi sosial yang melakukan berbagai kegiatan sosial seperti pengelolaan limbah non-B3 melalui ekonomi kreatif oleh anak jalanan yang berada di sekitar lokasi. Yayasan yang memiliki visi sebagai pusat pelatihan kewirausahaan sosial dan pemberdayaan masyarakat berbasis kepedulian lingkungan ini didirikan tanggal 20 Desember 2008 dan berlokasi di Jl. Sungai Bambu No 44 RT 01/08, Kelurahan Sungai Bambu, Kecamatan Tanjung Priok, Jakarta Utara.

Sama seperti dengan organisasi nirlaba lainnya, Yayasan Kumala juga diharuskan untuk menyusun laporan keuangannya sebagai bentuk pertanggungjawaban dari manajemen kepada masyarakat, lebih tepatnya kepada para donatur. Selama ini Yayasan Kumala menyusun laporan keuangannya dengan pembukuan yang sangat sederhana dan belum sesuai dengan Pedoman penyusunan SAK No. 45 (Pedoman SAK No. 45).

Berangkat dari adanya perbedaan dalam menyusunan laporan tersebut, maka kami berinisiatif melakukan bimbingan dan pelatihan penyusunan laporan keuangan di yayasan Kumala sebagai bentuk pengabdian kepada masyarakat.

Tujuan dari kegiatan ini yaitu:

1. Yayasan Kumala mampu menyajikan laporan keuangan yang sesuai standart yang berlaku.

2. Menjadikan entitas nirlaba yang berkelanjutan dan berkontribusi pada kesejahteraan masyarakat 
Manfaat kegiatan ini antara lain:

1. Bagi Pelaksana Kegiatan

a. Menciptakan suatu metode yang mampu digunakan oleh Yayasan Kumala dalam menyajikan laporan keuangan

b. Meningkatkan akuntanbilitas pengelolaan keuangan entitas

2. Bagi Akademik

Institut STIAMI dapat memberikan kontribusi bagi masyarakat DKI Jakarta sebagai wujud dari Tridharma Perguruan Tinggi.

\section{Permasalahan}

1. Bagaimana penyajian Laporan Keuangan Yayasan Kumala secara keseluruhan?

2. Bagaimana penyajian Laporan Keuangan Yayasan Kumala pada setiap project-nya?

\section{PELAKSANAAN DAN METODE}

Tahap pertama melakukan pengamatan terhadap Yayasan Kumala, ternyata ditemukan penyusunan laporan keuangan tidak sesuai dengan standart. Laporan hanya mencatat penerimaan dan pengeluaran kas. Laporan keuangan yang sesuai dengan Pedoman SAK No.45 meliputi Laporan Posisi Keuangan, Aktivitas, Perubahan Ekuitas, Laporan Arus Kas, dan Catatan atas Laporan Keuangan.

Sehingga, prioritas masalah yang akan dibantu adalah meningkatkan kemampuan personel Bank Sampah Yayasan Kumala dalam hal penyusunan laporan keuangan bank sampah yang sesuai dengan standar yang berlaku.

Solusi yang ditawarkan adalah dengan menggunakan suatu sistem (excel) dalam proses pencatatan sampai dengan penyusunan laporan keuangan.Selain itu akan diadakan bimbingan dan pelatihan mengenai penyusunan laporan keuangan kepada sumber daya manusia di Yayasan Kumala tersebut. Karena suatu sistem yang baik, harus dikelola olehsumber daya yang baik pula.

\section{Tahap Survey}

Survey awal dilakukan oleh peneliti di Yayasan Kumala yang berada di Tanjung Priok, Jakarta Utara. Di Yayasan Kumala ini banyak sekali aktivitas yang dilakukan dan perlu adanya dokumentasi apabila dilihat dari sisi keuangannya.

Tujuan dari survey ini adalah untuk mencari tahu masalah - masalah apa yang dihadapi oleh Yayasan Kumala saat menyusun laporkan keuangannya.

Dari hasil survey lapangan ditemukan fakta dimana Yayasan Kumala belum mampu menyusunan laporan keuangan yang sesuai dengan standar yang berlaku (Pedoman SAK No. 45). Ketidakmampuan tersebut disebabkan oleh hal - hal berikut:

- Kurangnya informasi mengenai standar pelaporan yang berlaku.

- Tidak adanya SDM berpengalaman dalam penyusunan laporan entitas nirlaba

Berangkat dari masalah tersebut, peneliti menjembatani dengan cara memberikan bimbingan dan pelatihan untuk menyusun laporan sesuai dengan Pedoman SAK No. 45.

\section{Solusi Dari Permasalahan}

Solusi dari permasalahan yang terjadi di Yayasan Kumala antara lain:

1. Bimbingan dan pelatihan SDM untuk menyusun laporan keuangan yang sesuai standar.

2. Memberikan sebuah sistem (excel) yang dapat digunakan oleh SDM Yayasan Kumala untuk membantu proses penyusunan laporan keuangan.

\section{Tahapan Pelaksanaan}

Tahapan pelaksanaan kegiatan ini adalah:

1. Kegiatan pembelajaran

Pada tahap ini, dilakukan pertemuan antara peneliti dengan personel Yayasan Kumala untuk memberikan penjelasan mengenai materi Pedoman SAK No. 45 baik secara ceramah ataupun demontrasi. Selain itu, dilakukan sesi tanya jawab dengan personel Yayasan Kumala. 


\section{Review}

Setelah para personel Yayasan Kumala sudah memahami mengenai PSAK No. 45, peneliti dan personel Yayasan Kumala akan melakukan evalausi atas laporan yang selama ini dibuat agar diketahui kesalahan yang selama ini terjadi.

\section{Tindak Lanjut}

Perbedaan yang ditemui pada tahap review akan ditindaklanjuti dengan cara melakukan penyusunan kembali laporan sesuai dengan standar akuntansi yang berlaku dengan menggunakan sistem excel yang sudah peneliti berikan.

4. Pendampingan

Proses menyajikan kembali laporan keuangan yang sesuai Pedoman SAK No. 45, peneliti tetap mendampingi selama masa pengabdian.

\section{HASIL DAN PEMBAHASAN}

Selama ini Yayasan Kumala mempunyai permasalahan mengenai penyusunan laporan keuangan yang tidak sesuai dengan standar akuntansi keuangan yang berlaku di Indonesia. Hal tersebut disebabkan oleh kurangnya informasi mengenai standar akuntansi keuangan yang berlaku di Indonesiasaat ini dan tidak adanya SDM yang berpengalaman dalam penyusunan laporan keuangan entitas nirlaba.

Oleh karena itu, peneliti melakukan bimbingan dan pelatihan kepada personel Yayasan Kumala mengenai penyusunan laporan keuangan bagi entitas nirlaba, mulai dari pemaparan materi, demonstrasi, serta pendampingan kepada personel dalam proses penyusunan laporan keuangannya.

Dalam proses bimbingan dan pelatihan, materi - materi yang diberikan disesuaikan dengan pedoman SAK No. 45. Selain pemaparan materi mengani Pedoman SAK No.45, peneliti juga menyediakan sistem (excel) untuk mempermudah proses pencatatan hingga penyusunan laporan keuangannya. Pada sistem ini terdapat beberapa menu seperti yang tertera pada gambar diatas. Langkah - langkah yang perlu dilakukan oleh personel Yayasan Kumala dalam melakukan proses pencatatan sampai dengan penyusunan laporan keuangan..

Hasil dari pengabdian kepada masyarakat yang peneliti lakukan di Yayasan Kumala, yaitu:

1. Melakukan kegiatan pembelajaran, yaitu dengan memberikan memberikan penjelasan mengenai materi PSAK No. 45 baik secara ceramah ataupun demontrasi. Dalam tahap ini terjadi tanyajawab mengenai akuntansi keuangan, PSAK No 45, dan hal lain yang berhubungan dengan entitas nirlaba.

2. Melakukan review atas laporan yang ada saat ini, dan melakukan analisa apakah telah sesuai dengan PSAK No. 45.

3. Menindaklanjuti ketidaksesuaian pada saat melakukan review dengan cara melakukan penyusunan kembali laporan keuangan yang sudah dibuat dengan bantuan sistem (excel) yang diberikan oleh peneliti.

4. Melakukan pendampingan kepada personel Yayasan Kumala yang melakukan penyusunan kembali laporan keuangan selama masa pengabdian.

\section{PENUTUP}

\section{Simpulan}

Yayasan Kumala adalah sebuah entitas nirlaba yang melakukan kegiatan sosial pengembangan ekonomi masyarakat, diantaranya pengembangan kewirausahaan. Yayasan Kumala melakukan berbagai kegiatan sosial seperti pengelolaan limbah non-B3 melalui ekonomi kreatif oleh anak jalanan yang berada di sekitar lokasi.

Selama ini Yayasan Kumala menyusun laporan pertanggungjawabannya hanya berdasarkan pembukuan yang sederhana dan tidak sesuai dengan standar berlaku bagi entitas nirlaba. Penulis melakukan bimbingan dan pelatihan mengenai penyusunan laporan keuangan yang sesuai dengan Pedoman Standar Akuntansi Keuangan No. 45 (PSAK No. 45). 


\section{DAFTAR PUSTAKA}

Pedoman SAK 45 Pelaporan Keuangan Entitas Non Nirlaba. Jakarta: Ikatan Akuntansi Indonesia.

Hery. (2014). Pedoman Praktis Menyusun Laporan Keuangan. Jakarta, Grasindo.

Stice, Earl K., James D., dan Skousen, K. Fred. 2009. Intermediate Accounting, Jakarta, Salemba Empat.

Baridwan, Zaki, 2004. "Intermediate Accounting”, Edisi 8, Yogyakarta, BPFE Yogyakarta

Dinsos. (n.d.). Peduli Lembaga Kesejahteraan Sosial. Retrieved from http://peduli.pusdatindinsos.jakarta.go.id

Martani, D. (2018, September 12). Dwi Martani Accounting \& Finance Corner. Retrieved from Blog Staff Universitas Indonesia

Wikipedia. https://id.wikipedia.org/wiki/Laporan_keuangan

\section{Dokumentasi}
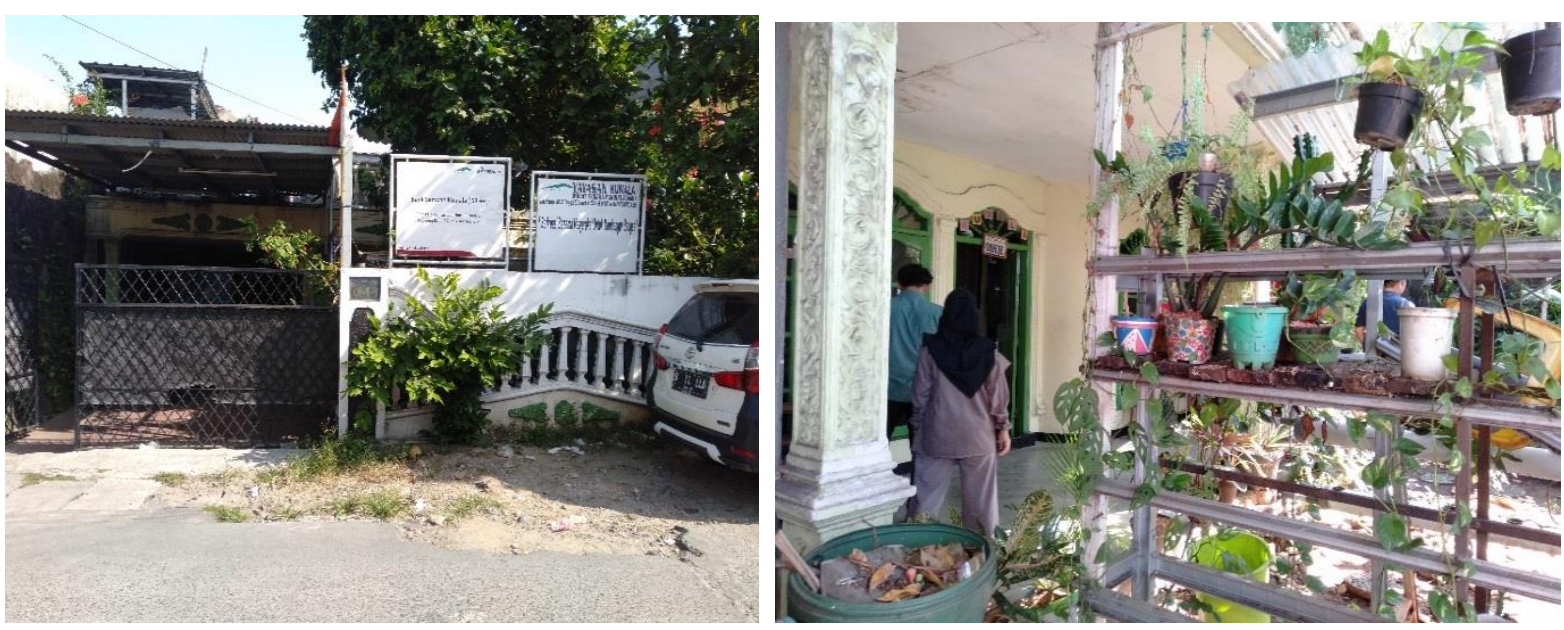

Lokasi Pusat kegiatan Yayasan KUMALA

\section{Halaman depan Yayasan KUMALA}
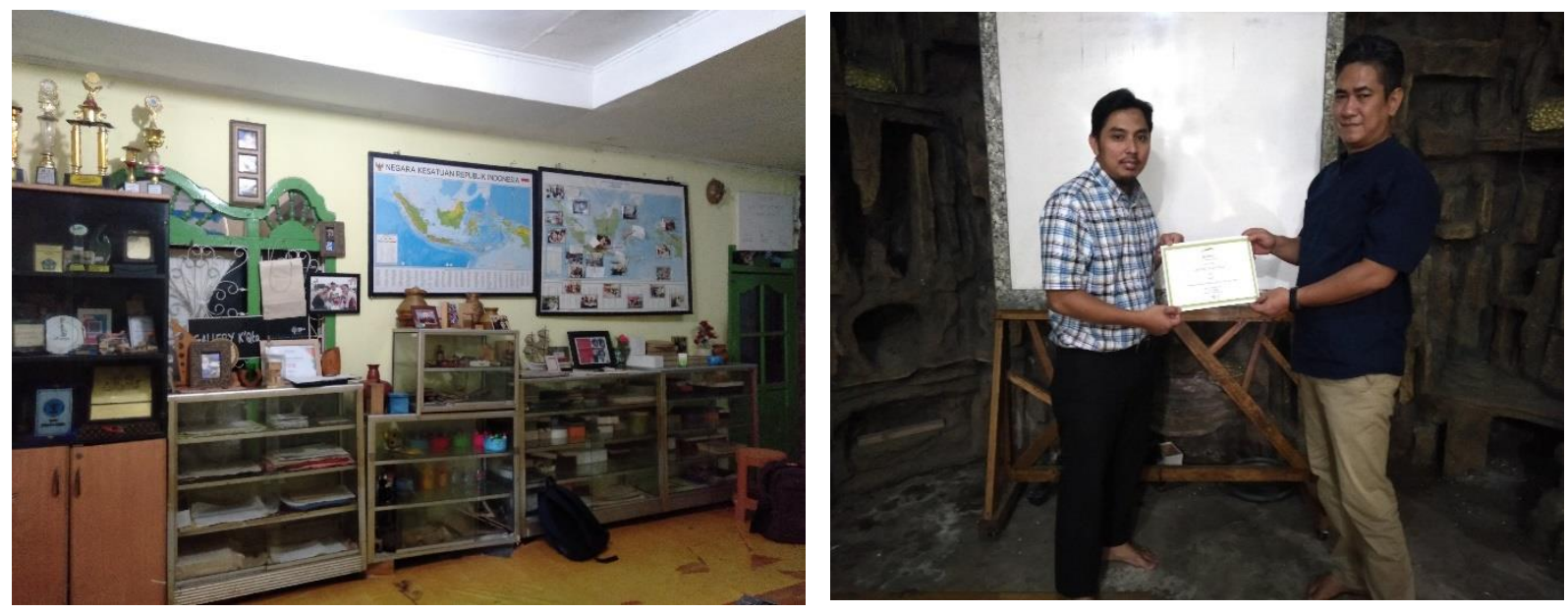

Display hasil karya dan Penghargaan yang

Pemberian sertifikat sebagai simbolis dari Ketua diterima Yayasan KUMALA

Pelaksana kepada Pengurus Yayasan KUMALA 